\title{
Lesya Ukrainka's Poetry in Chinese Translation: Psycholinguistic Aspect*
}

\section{Поезія Лесі Українки в китайськомовному перекладі: психолінгвістичний аспект*}

\author{
Natalia Isaieva ${ }^{1}$ \\ Dr. Sc. in Philology, \\ Associate Professor
}

\author{
Наталя Ісаєва ${ }^{1}$ \\ доктор філологічних наук, \\ доцент
}

\author{
E-mail: inattalia@gmail.com \\ https://orcid.org/0000-0002-8458-4650 \\ ResearcherID: AAX-2599-2021
}

\begin{abstract}
Alina Akimova ${ }^{2}$
Ph.D. in Philology,

Assistant Professor
\end{abstract}
Аліна Акімова 2
кандидат філологічних наук, доцент
E-mail: a_alina09@ukr.net
https://orcid.org/0000-0001-7546-2902
ResearcherID: C-5824-2017

\begin{abstract}
Anastasiya Akimova ${ }^{1}$
Анастасія Акімова ${ }^{1}$

Student

Студентка

E-mail: nastia.a@ukr.net

https://orcid.org/0000-0002-3484-7205
\end{abstract}

\section{Svitlana Chernyshova ${ }^{1}$}

Ph.D. in Philology,

Assistant Professor

\section{Світлана Чернишова ${ }^{\mathbf{1}}$}

кандидат філологічних наук, доцент

E-mail: sveta.chernyshova@gmail.com https://orcid.org/0000-0003-0284-2001

\footnotetext{
* This study is done within the framework of the State project (Registration number 20КП044-08).

** Дослідження виконане в рамках НДР (реєстраційний номер 20Кп044-08).
} 
Поезія Лесі Украӥнки в китайськомовному перекладі...

${ }^{1}$ Taras Shevchenko National

University of Kyiv (Ukraine)

14, T. Shevchenko Boul., Kyiv, Ukraine, 01601

${ }^{2}$ Interregional Academy of Personnel

Management (Ukraine)

2, Frometivska Str., Kyiv, Ukraine, 203039
${ }^{1}$ Київський національний

університет імені Тараса

Шевченка (Украӥна)

бульвар Т. Шевченка, 14, Київ, Україна, 01601

${ }^{2}$ Міжрегіональна Академія управління персоналом (Україна)

$\bowtie$ вул. Фрометівська, 2, Київ, Україна, 203039

Original manuscript received December 29, 2020

Revised manuscript accepted September 25, 2021

\section{ABSTRACT}

Aim of the study. On the basis of the theories of dynamic translation, determine the degree of correspondence between the psycho-cognitive reactions of Ukrainian and Chinese recipients to the original and translated texts of the poetry-cycle of Lesya Ukrainian "Tears-Pearls".

Research methods. Psycholinguistic methods of empirical research are basic in this article: Osgood's semantic differential method, content analysis and free associative experiment, other linguistic methods (cognitive and semantic analysis) and general scientific methods (analysis, synthesis, description and classification of linguistic facts) are also used.

Results. On the basis of previous theoretical studies, the essential characteristics of translation as a psycho-cognitive process have been established. It is argued that the degree of equivalence of the translation of a literary text is determined not only by the work of the translator, but also by the emotional-evaluative reaction of the target recipients. An important thesis is that the perception of the text (original and translation) is influenced by the interhemispheric asymmetry of the mental activity of speakers of different languages (Clark \& Paivio, 1991; Fenollosa, 1968; Zasyekin, 2010). Empirical research has shown that the "right-brain" imaginative thinking of the Chinese partly determines the degree of equivalence of their perception of the translation of Lesya Ukrainka's poetry. The semantic profiles showed a fairly neutral emotional and evaluative reaction of the Chinese to translation incentives, which, in our opinion, was conditioned by the ethnonational specifics of the original text and the difference in poetic traditions. Despite the preservation of the thematic categories of the original in translation, in the new (Chinese) semantic space, these categories partly acquired other sociocultural meanings, which significantly influenced the equivalence of the translation.

Conclusions. The degree of conformity of the psycho-cognitive reaction of target recipients to the original and the translation is determined not only by the type of mental activity of speakers of different languages, but also by a number of 
extralinguistic factors that determine the formation and state of activity of the verbalassociative network of representatives of different nations.

Key words: chinese language, translation, Lesya Ukrainka, dynamic equivalence, semantic differential, semantic space.

\section{Introduction}

Over the past four decades, scholars have studied translation not only as a linguistic phenomenon but also as a complex cognitivepsychological process. Translation researchers

"aiming to discover what translators actually do and what is going on in their minds when they translate" (Zheng \& Xiang, 2017).

Therefore, translation science actively uses research methods of psycholinguistics, sociolinguistics, cognitive linguistics, communication theory and so on. In the late 1980s, Schweitzer (1988: 21) concluded that the discovery of the psychological basis of translation is a prerequisite for understanding its essence. British linguist R.T. Bell expressed a similar view, emphasizing the need to study translation not only as the product (text) but also as the mental process:

“... we have a responsibility to try to describe and explain the process and that the process itself is, essentially, mental rather than physical, we are committed to undertaking the investigation within the discipline of psychology and, more specifically, within the framework of psychological studies of perception, information processing and memory..." (Bell, 1991: 13).

As you know, the object of psycholinguistics is speech activity, the object of translation theory is a special type of speech activity associated with interlingual communication. Thus, both branches of science tend to have common tasks and methods of research of language material. Eugene Nida defines translation as

"the reproduction in a receptor language of the closest natural equivalent of the source language message, first in terms of meaning, and second in terms of style" (Nida \& Taber, 1982: 208).

This definition contains three essential terms related to the concept of dynamic equivalence: 
“(1) equivalent, which points toward the source-language message,

(2) natural, which points toward the receptor language, and

(3) closest, which binds the two orientations together on the basas of the highest degree of approximation" (Nida, 1964: 166).

It is obvious that the psycholinguistic direction of translation studies stimulated the development of empirical research, because methodologically, psycholinguistics has a strong focus on experimentation, precise measurements and statistical analysis of data (Zheng \& Xiang, 2017: 292). Empirical studies of translation intensified in the 1990s, but a decade earlier, scholars had already predicted the development of "an empirical discipline" (Holmes, 1988: 71). AmericanDutch translation scholar James S. Holmes, based on the ideas of Carl G. Hempel, identified the main objective of empirical research:

"to describe the phenomena of translating and translation (s) as they manifest themselves in the world of our experience" (Holmes, 1988: 71).

Currently, domestic and foreign scientists focus on the study of a number of problems with the use of experimental methods, in particular: the phenomenon of interlingual asymmetry in translation with the application of testing the sense model (Wang \& Forster, 2010), cross-cultural adaptation and psychometric evaluation of the Yoruba version of the English medical questionnaire (Mbada et al., 2020); the process of oscillatory modulations during translation and reading tasks in professional simultaneous interpreters (PSIs) and non-interpreter bilinguals (NIBs) (Dottori et al., 2020); psychological and psycholinguistic aspects translation-oriented reading vs ordinary reading with the application of cognitive approach suggests (Dolzhikova et al., 2018); mechanism of information processing by a translator using the Think-Aloud method of data elicitation (Bogusławska-Tafelska, 2001); the adequacy of translations to the original in terms of the recipient's aesthetic response with the application of Osgood's Semantic Differential and the associative test (Zasyekin, 2010) etc.

However, in modern translation studies there is a significant gap (a major gap exists towards) in the study of the psychocognitive mechanism of information processing of original and translated texts, in particular, 
"in terms of associative networks of verbal and nonverbal mental representations" (Clark \& Paivio, 1991: 157).

This is especially true of translations from European to Eastern languages, including Chinese. Therefore, the object of our research is Lesya Ukrainka's poetic cycle "Tears of Pearls" and its translation into Chinese as a psycholinguistic phenomenon. The aim of the study is to determine the degree of conformity of the psychocognitive reaction of Ukrainian and Chinese recipients to the original and translated texts.

\section{Research methods}

The presented study was conducted in three stages. At the first stage, the method of Osgood's semantic differential was used to determine the aesthetic reaction of Ukrainian and Chinese recipients to the poetic text. The Oxford Dictionary of Psychology defines the semantic differential as

"a device for measuring the affective or connotative meaning of the words..." (Colman, 2015: 395).

This method, as claimed by Osgood, Suci and Tannenbaum (1957), proves to be universal for speakers of different languages. At the second stage, a content analysis was performed in order to identify and compare the characteristics of the main categories of original and translated texts. In general,

"content analysis is a research tool used to determine the presence of certain words, themes, or concepts within some given qualitative data (i.e. text). Using content analysis, researchers can quantify and analyze the presence, meanings and relationships of such specific words, themes, or concepts" (Population Health Methods, 2019).

At the final stage, the word-association test was involved as

"a technique aimed at revealing aspects of unconscious mental processes, enabling the analyst to focus on the key areas of psychological significance of a verbal stimulus for a respondent" (Colman, 2015: 475).

Based on this method, the semantics of associative fields of verbal stimuli for recipients of original and translated texts was established. 


\section{Theoretical study of the problem}

Chinese readers first became acquainted with Lesya Ukrainka's work in 1921. It was then that the famous Chinese writer and translator Mao Dong published his translation of the drama The Babylonian Captivity in Xiaoshuo Yuebao magazine (Fiction Monthly). He made this translation from the English edition of "Five Russian plays: with one from Ukrainian" edited by S.E. Bechhofer Roberts. Since then, more than 20 of Lesya Ukrainka's poetic and prose works have been translated into Chinese, but to date they have not been thoroughly researched. An exception is several articles by Ukrainian orientalist Ogneva (1993; 2008; 2012), in which she explored the motivation of Chinese translators to turn to Lesya Ukrainka's work, as well as outlined the ethnocultural and ethnopsychological aspects of translations. Analyzing the peculiarities of Ge Baoquan's translations, Ogneva noted the importance of reproducing the thoughts and images of the original by means of the Chinese language, taking into account a different reality and a different perception. At the same time, she stressed that many things are not expressed in art and literature, there is only a hint,

"the connection of lines and images does not arise at the grammatical or even logical level - it is associative, at the subconscious level" (Ogneva, 2012: 58).

This observation is important for our study because Chinese language thinking is a reflection of a hieroglyphic culture that is essentially image-associative. It should be assumed that this inevitably affects the translation process and its outcome.

According to A. Paivio's dual coding theory (DCT), when processing information, the interpreter works with two subsystems: verbal-logical and non-verbal-image. The interaction of these subsystems is determined by the division of the human brain into two hemispheres, each of which has its own specialization.

"The left hemisphere is clearly responsible for language, conceptualization and verbal logical (rational) thinking. The right hemisphere, on the contrary, processes more "concrete", emotionally loaded information, i.e. images, which accompany verbal information" (Zasyekin, 2010: 226). 
During the processing of information in the mind of the interpreter in different ways activated verbal and figurative associative structures. According to Clark and Paivio,

"strong activity may be associated with conscious nonverbal and verbal experiences..., although arousal of codes does not always lead to conscious experiences" (Clark \& Paivio, 1991: 154).

It should be assumed that the way of perception and thinking of speakers of different languages also affects the degree of activation of the relevant structures. Recent research has shown that Chinese (hieroglyphic) speakers actively engage "right-hemispheric spatial thinking with its holistic information processing strategy", while native speakers of alphabetic languages (eg. Ukrainian) use mainly "lefthemisphere logical-verbal thinking" (Rubets, 2009: 115). It is probable that poetic discourse only reinforces this feature. The famous American orientalist Ernest Fenollosa in his essay "The Chinese Written Character as a Medium for Poetry" (Fenollosa, 1968) compared the poetic possibilities of Chinese and English. In contrast to the dry logic of the alphabetic English language, the scientist found in Chinese hieroglyphic writing a concrete and figurative perception of the world in its dynamic unity. Fenollosa noted:

"Chinese poetry has the unique advantage of combining both elements. It speaks at once with the vividness of painting, and with the mobility of sounds. It is, in some sense, more objective than either, more dramatic. In reading Chinese we do not seem to be juggling mental counters, but to be watching things work out their own fate" (Fenollosa, 1968).

Summarizing the above, it should be assumed that the degree of correspondence between the original and translated texts is influenced by the interhemispheric asymmetry of mental activity of speakers of different languages. To test this thesis on the example of the Chinese translation of Lesia Ukrainka's poetic cycle "Pearl Tears" (Lesia Ukrainka, 1962), we used the theory of dynamic equivalence (see introduction). Nida and Taber put forward the concept of dynamic equivalence as opposed to formal equivalence, which is basically sourseoriented, in other words it focuses attention on the message itself, in both form and content. Dynamic equivalence is directed primarily towards receptor response; it means 
"the quality of a translation in which the message of the original text has been so transported into the receptor language that the response of the receptor is essentially like that of the original receptors" (Nida \& Taber, 1982: 200).

Nida's theory of dynamic equivalence became one of the ones that directed translation studies in the direction of psycholinguistics, consolidating the important place of the translator and recipients in the systematization of the translation process. The basic categories - the actual translation and its equivalence - have acquired an anthropological interpretation. Accordingly, new translation evaluation criteria have emerged. According to the conclusions of Schweitzer (1988), the quality of translation is determined by the attitude of the addressee, attention to communicative intention and communicative effect. Therefore, considerable attention of researchers began to be paid not only to the personality of the translator, but also to the personality of the addressee. In particular, Latyshev (2000) puts forward the concept of linguoethnic equivalence, or overcoming the linguoethnic barrier. The point is that in the process of translation it is necessary to take into account the active state of the verbal-associative network of the recipient (addressee) a representative of another national-cultural community. This causes not only the equal impact of the original and translated text on their recipients, but also a similar emotional and evaluative reaction.

\section{Procedures of the Empirical Research}

Participants. As respondents, 40 native Ukrainian speakers (aged 19 to 22) and 32 native Chinese speakers (aged 19 to 35) took part in the experiment (most of them are students and postgraduates of Taras Shevchenko National University of Kyiv).

Adherence to Ethical Standards. The non-written consent was obtained from potential participants of the experiment to take part in the research. The authors did not receive financial support from any organization to conduct their research. The authors did not have any financial interests to disclose.

In order to determine the correspondence of the Chinese translation to the Ukrainian original in terms of the aesthetic reaction of the recipient, we conducted an experiment using the semantic 
differential of Osgood. The feasibility and efficiency of using this method to evaluate translation were demonstrated by Zasyekin (2010). The semantic differential is a combination of the method of controlled associations and the scaling procedure.

At the first stage, the native Ukrainian speakers differentiated the text of Lesya Ukrainka's poetic cycle "Tears-Pearls" on the basis of evaluation, potency and activity factors. Through a series of statistical analyzes, Osgood (1952) identified these three stable factors by which people can judge almost anything. Each factor contained 4 to 6 sevenpoint bipolar scales, the end-points of which were anchored with antonymic adjectives (e.g., good - bed, beautiful - disgusting, strong weak, clear - blurred, active - passive, etc.). Scores ranged from -3 at the negative end of each scale to +3 at the positive end. The subjects were instructed to mark a chosen number. The responses showed the respondents 'subjective judgment of the stimulus (poetic text) (Zasyekin, 2010). At the second stage, native Chinese speakers followed the same procedure when evaluating Mei Shenhe's Chinese translation. As a result, semantic profiles of the source text and translation were drawn up (Fig. 1).

\section{Figure 1}

Semantic profiles of the original text and its Chinese translation

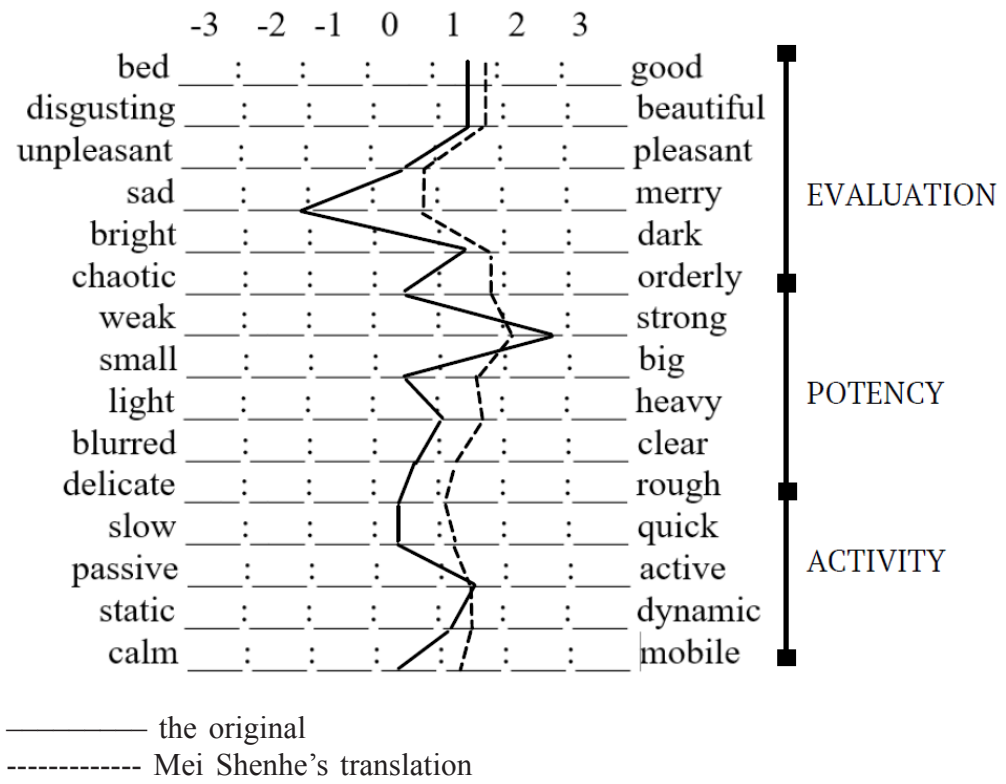




\section{Results}

The data underlying this article are available in Social Science Research Network (SSRN) (Isaieva, 2021).

It was found that the semantic profile of Ukrainian respondents is more amplitude than the profile of Chinese respondents, ie the emotional and evaluative reaction to the stimulus-translation of Chinese speakers is quite neutral. It ranges from 0 to +1.3 . The greatest difference between the semantic fields of the original and the translation can be traced by the factors of evaluation and potency. For example, on the scale "sad-marry" the difference is about 2 points. Ukrainian respondents perceive the poem as rather sad and mournful (unequivocally negative connotation), while the Chinese show a restrained emotional reaction, which is fixed by the number 0 . On the scale of "weak-strong" the difference is about 1 point: for Ukrainians the original poem sounds quite powerful, while the Chinese only slightly feel the intensity of the sound of the translation. Nevertheless, the reaction of all respondents is close in terms of activity, in particular, on the scale of "active-passive" it was identical $($ about +1$)$. Thus, Mei Shenhe managed to recreate the emotional palette of Lesya Ukrainka's poetry only partially. This is due, in our opinion, to several reasons: (1) ethno-national labeling of the original text, which does not activate figurative associations in the minds of Chinese recipients; (2) the difference in the traditions of poetic creativity. An additional survey of Chinese respondents testifies in favor of the latter. They evaluated the translation according to three criteria, fundamental in Chinese translation studies: 信 (faithfulness) - completeness of reproduction of the original's content, 达 (expressiveness) - clarity and sequence of translation (by form), 雅 (elegance) - conciseness and elegance of vocabulary in translation. The first criterion concerns the understanding of foreign readers of the content of translation, the other two - the Chinese national specifics of poetic texts (in particular, "laconicism and sophistication of vocabulary" - an important feature of Chinese traditional poetry written in the ancient Wenyan language). Therefore, the respondents noted in Mei Shenhe's translation a sufficient completeness of the reproduction of the content, but underestimated it according to the criteria of "expressiveness" and "elegance". This conclusion confirms the results of our experiment. 
Content analysis of the poetic cycle of Lesya Ukrainka and its Chinese version made it possible to identify the main thematic categories and compare the semantic content of these categories in the original and translation. The analysis identified 6 basic categories in both texts: “homeland / 贵土”, “family / 家庭”, “suffering / 痛苦”, “struggle / 战斗”, “death / 死亡”, “freedom / 自由”. Most of these categories are the basic concepts of the Ukrainian national world picture. These concepts are connected with important stages of Ukrainian history, they are artistically reflected in the works of Lesya Ukrainka and other artists. Malanyuk called Lesya Ukrainka the «national phenomenon»,

"the manifestation of the nation on the eve of its political revival and late cultural self-awareness" (Malanyuk, 1962: 94).

All these categories exist in the language mentality of Ukrainians. It is expected that the lexical content of these categories in the original and translation has differences, as evidenced by Table 1 (in parentheses indicates the frequency of use of tokens).

Table 1

Lexical content of basic categories in Lesya Ukrainka's poetic cycle "Tears-Pearls" and in its Chinese translation

\begin{tabular}{|c|c|c|c|}
\hline № & Category & Original & Chinese translation \\
\hline 1 & $\begin{array}{l}\text { Рідний край / } \\
\text { 贵土 } \\
\text { (Homeland) }\end{array}$ & $\begin{array}{l}\text { Україна / Ukraine (2), земля / } \\
\text { land (2), сторононька рідна / } \\
\text { native land (1), коханий } \\
\text { краю / beloved land (1) }\end{array}$ & $\begin{array}{l}\text { 乌克兰 / Ukraine (3), 亲爱的祖国 / } \\
\text { dear motherland (1), 可爱的疆土 / } \\
\text { lovely territory (1), 大地 / land (1) }\end{array}$ \\
\hline 2 & $\begin{array}{l}\text { Родина / 家庭 } \\
\text { (family) }\end{array}$ & $\begin{array}{l}\text { Душа / soul (5), серце / heart } \\
\text { (4), серденько / heart (2), } \\
\text { брати / brothers (2), люде / } \\
\text { реople (1), родина / family (1), } \\
\text { діти / children (1), дитячі / } \\
\text { children's (1), ненька / mother } \\
\text { (1), матір / mother (1) }\end{array}$ & $\begin{array}{l}\text { 心 / heart (5), 心儿 / heart (4), 心头 } \\
\text { mind, heart (1), 心灵 mind, soul } \\
\text { (1), 灵 / spirit, soul (1), 灵魂 / soul, } \\
\text { spirit (1), 母亲 / mother (2), 儿女 / } \\
\text { children (2), 兄弟 / brothers (1), 人民 / } \\
\text { people (1) }\end{array}$ \\
\hline 3 & $\begin{array}{l}\text { Страждання / } \\
\text { 苦痛 } \\
\text { (suffering) }\end{array}$ & $\begin{array}{l}\text { Сльози / tears (7), плакати / } \\
\text { сry (4), туга / sorrow (4), } \\
\text { ридання / sobbing (2), } \\
\text { ридати / sobbing (2), терпіти / } \\
\text { tolerate, suffer (2), тяжкий / } \\
\text { hard (2), безщасний / unhappy } \\
\text { (1), недоля / misfortune, } \\
\text { misery (2), неволя / bondage } \\
\text { (1), журба / sorrow (1), лихо / } \\
\text { disaster (1), горе / grief (1) }\end{array}$ & $\begin{array}{l}\text { 泪 / tears (2), 眼泪 / tears, crying (4), } \\
\text { 苦泪 / bitter tears (1), 哭泣 / weep (1), } \\
\text { 号哭 / cry loudly (1), 受难 / suffer a } \\
\text { calamity (1), 不自由 / lack of freedom } \\
\text { (1), 悲叹 / sigh mournfully (1), } \\
\text { 不幸 / misfortune (2), 多么不幸 / how } \\
\text { unfortunate (3), 忧愁 / sad (1), 沉睡 / } \\
\text { fast asleep (1), 苦难 / sufferings (1), } \\
\text { 苦痛 / suffering (1) 哀恸 / feel deeply } \\
\text { grieved (1), 忧怨 / grief and hatred (1) }\end{array}$ \\
\hline
\end{tabular}


Поезія Лесі Украӥнки в китайськомовному перекладі...

\begin{tabular}{|c|c|c|c|}
\hline 4 & $\begin{array}{l}\text { Боротьба / } \\
\text { 战斗 } \\
\text { (struggle) }\end{array}$ & $\begin{array}{l}\text { Палають, запалають / burn } \\
\text { (4), палили / burn (1), } \\
\text { палкі (2), огнистий / fiery } \\
\text { (1), повстане, повстанем / } \\
\text { rebel (4), боротись / struggle } \\
\text { (1), розбудить / will wake } \\
\text { up (1), переможе / will win } \\
\text { (1), перемога / victory (1), } \\
\text { одвага / courage (1) }\end{array}$ & $\begin{array}{l}\text { 燃烧 / burn (4), 热情 / ardour (2), } \\
\text { 获胜 / win victory (1), 英勇奋斗 / } \\
\text { valiant struggle (1), 战斗 / struggle (1), } \\
\text { 勇敢 / brave (1), 苏醒 / 醒来 / wake } \\
\text { up (2), 燃起 / ignite (1), 烈火熊熊 / } \\
\text { light the flames (1), 振奋起来 / cheer } \\
\text { up (1), 抗争 / resist (1) }\end{array}$ \\
\hline 5 & $\begin{array}{l}\text { Смерть / 死亡 } \\
\text { (death) }\end{array}$ & $\begin{array}{l}\text { Темний / dark (2), темнота / } \\
\text { darkness (1), замовкло/ } \\
\text { замовкне / silence (2), } \\
\text { заніміло / was numb (1), } \\
\text { загине / will die (1), до } \\
\text { загину / to death (1), } \\
\text { погибель / death (1), } \\
\text { в могилі / in the grave (1), } \\
\text { смерть / death (1), смертна / } \\
\text { mortal (1) }\end{array}$ & $\begin{array}{l}\text { 沉默 / silence (1), 麻木 numbness } \\
\text { (2), 不唱了 / did not sing (1), 寂 } \\
\text { 寞 / silent (1), 黑暗无光 / dark (1), } \\
\text { 黑幕 / black veil (1), 牺牲 die a } \\
\text { martyr's death (1), 坟墓 / tomb (1), } \\
\text { 死的 dead (1), 该死的 damnable (1) }\end{array}$ \\
\hline 6 & $\begin{array}{l}\text { Воля / 自由 } \\
\text { (freedom) }\end{array}$ & $\begin{array}{l}\text { Сили / power (4), без сили / } \\
\text { without force (1), воле freedom } \\
\text { (1), зоре / dawn (1), правду / } \\
\text { truth (1) }\end{array}$ & $\begin{array}{l}\text { 力量 / power (1), 无力 / powerless (1) } \\
\text { 自由 / freedom (1), 不自由 / bondage } \\
\text { (1), 星光 / starlight (1) }\end{array}$ \\
\hline
\end{tabular}

The table shows that the categories "family", "suffering", "struggle", "death" are the most meaningful, both in the original and in translation. According to their lexical content, these categories, at first glance, are approximately the same in both texts, however, there are differences. In particular, the category "family" in the original text is most often expressed by two tokens душа / soul (5) і серие, серденько / heart (6). In the Chinese translation, these tokens correspond to a number of synonyms that create a broader semantic field, namely: 心 / heart (5), 心儿 / heart (4), 心头 / mind, heart (1), 心灵 / mind, soul (1), 灵 / spirit, soul (1), 灵魂 / soul, spirit (1). However, it is worth paying attention to the figurative-visual component of the Chinese text, which often contains the determinant 心 heart (as an independent sign 心 or as part of other hieroglyphs 忄 ): 怯 / afraid, 愿 / desire, 恸 / sadness, 忧愁 / sad, 想 / think, 忍 / endure, 情 / feeling, 忧怨 / worries, 悲 / sorrow, 怜 / sympathy. Thus, the basic tokens 心 / heart and 灵 / spirit, soul are visually and associatively connected with words-emotives, which expand their semantic fields.

The lexical content of the category "struggle" has even more significant differences in the original and translation. In the Chinese 
text, established and idiomatic expressions are actively used, which are absent in Lesya Ukrainka's poem. For example, the expression 英勇奋斗 / valiant struggle specifies the action expressed by the verb повстанем / 将起来 will rise, and also gives it a bright emotional color. The expression 振奋起来 / cheer up is a situational equivalent of the verb повстане (душа) / (soul) rises, but with more specific semantics and a pronounced positive connotation. Finally, the idiomatic expression 烈火熊熊 / light the flames concretizes the verb 燃起 / ignite, giving it imagery, metaphor, and emotion. At the same time, all these expressions are often used in modern Chinese journalistic texts, which approve of the socio-political course of the country and glorify the achievements of the Chinese nation. Relevant semantic accents are transferred to the translation of Lesya Ukrainka's poetry.

Our free associative experiment confirmed and deepened the results of content analysis. The importance of FAE for this study is to identify not only the unconscious components of the semantic space of recipients of different languages, but also to determine the socio-cultural meanings of stimulus words. The stimulus words in our experiment were the analyzed categories. As a result of FAE, associative semantic universals of these stimuli were identified, ie a set of non-random associations for each stimulus word for a specific group of respondents (Serkin, 2004: 79-80). For example, such a semantic universal of the wordstimulus родина / family for Ukrainian recipients is mепло / warmth, (13), любов / love (11), батьки, тато й мама / parents (9), щзастя / happiness (4). The same reaction words were found in the responses of Chinese respondents 温暖 / warmth (6), 温馨 / warm, cosy (4), 爱情, 爱情, 热爱 / love, ardently love (6), 父母, 爸爸妈妈 / parents (4), 幸福 / happiness (6). Thus, the representatives of both groups are united by an irrational-sensual, "right-hemispheric" perception of the concept. At the same time, in the answers of Ukrainians non-random associations are дім / home (8), Батьківщиина / Homeland (2) Україна / Ukraine (3), that is the semantic universal of the word-stimulus родина / family contains a subconscious idea of the family as a specific country, the historical place of life of relatives people. That is, Ukrainians have a logical and conceptual "left hemisphere" perception. Such associations are absent in Chinese recipients, but there is the concept of 和睦, 和谐 / harmony (4), ie in the collective subconscious of the Chinese family must ensure a harmonious relationship between loved ones. The philosophy 
of Confucianism and Taoism, each of which sought to harmonize human life in its own way, played an important role in the formation of the semantic universality of the word-stimulus 家庭 / family. Based on the obtained universals, the degree of semantic similarity (synonymy) of the analyzed concepts was calculated by the formula:

$$
\mathbf{S}=\mathbf{C} /(\mathbf{N 1}+\mathbf{N 2}) \text {, }
$$

where $\mathbf{C}$ is the number of matching associations; $\mathbf{N 1}$ - total number of associations of Ukrainians; $\mathbf{N} \mathbf{2}$ - the total number of Chinese associations (Serkin, 2004: 79-80). The results are presented in Figure 2.

\section{Figure 2}

Semantic closeness of concepts in Ukrainian and Chinese languages

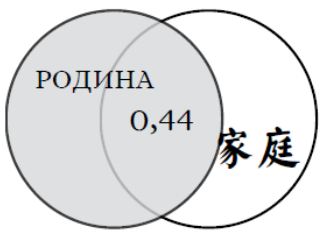

1. The concept "family"

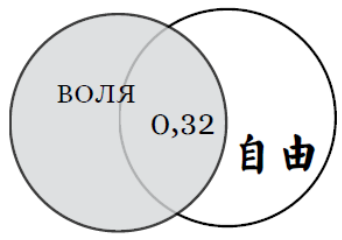

4. The concept "freedom"

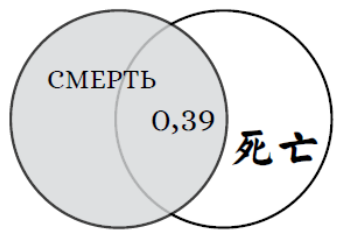

2. The concept "death"

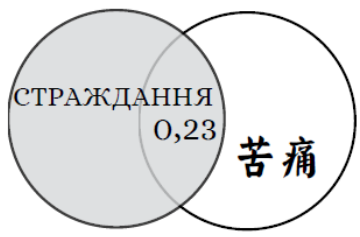

5. The concept "suffering"

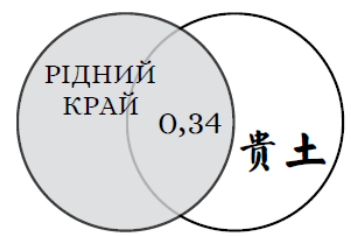

3. The concept "Homeland"

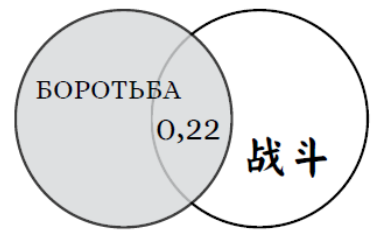

6. The concept "struggle"

As the figure shows, the semantic fields of the concepts "родина家庭 (family)" have the largest area of intersection, and therefore they have the greatest degree of semantic closeness - 0.44 (with complete coincidence of the fields, this degree is equal to 1). The concepts of “боротьба - 战斗 (struggle)" have the lowest degree of semantic similarity, respectively, it is equal to 0.22 . However, it is worth noting that the most frequent words-reactions of Ukrainian respondents in the associative semantic universal of the concept "боротьба (struggle)" are сила / strength (14), свобода, воля / freedom (9), незламність / indestructibility (3), перемога / victory (3), життя / life (3). Thus, for Ukrainians, this concept evokes logical abstract associations associated with the subconscious desire of Ukrainians to gain freedom and independence. In the context of current events, this perception of the 
struggle remains relevant, as these reactions account for $26.0 \%$ of all associations. The Chinese have $16.0 \%$ of such associations, with no "freedom" reaction, and all the others are represented by single answers. Instead, the most frequent reactions of Chinese respondents 血 / blood (5), 惨烈, 残忍 / tragic, brutal (3), 武器 / arms (2), 战士, 军士 / warrior (3), 斗争 / struggle (4), they are $34.0 \%$ of all associations (Ukrainian respondents - only 7.0\%). That is, the Chinese present the struggle in figuratively specific categories - as a picture of a brutal and bloody battle. This is evidenced, in particular, by the figurativesynonymous series of the reaction 血 / blood: 血液, 鲜血 / blood, 热血 / hot blood, 流血 / bloodshed. It is important that for Ukrainians the goal of the struggle is clearly defined - gaining freedom, for the Chinese it is ambiguous: 为一些事情而斗争 (fight for something), 为了保家卫国而战斗 (fight to defend our Homeland), 为和平而斗争 (fight for peace). Thus, the concept "struggle" is reflected differently in the semantic fields of Ukrainian and Chinese respondents. This conclusion is to some extent true for all the concepts identified in the poetic cycle of Lesya Ukrainka.

\section{Conclusions}

The study found that modern theories of dynamic translation, in particular Osgood's theory, are productive for studying the qualitative characteristics of translation not only as a result but also as a communicative process. That is, not only the work of the translator is taken into account, but also the emotional and evaluative reaction of the recipients. Empirical research has shown that the psychocognitive reaction of Ukrainian and Chinese recipients to the original and translated texts of Lesya Ukrainka's poetry is only partially equivalent. This is due not only to the dominant "right-hemispheric" (concreteimage) thinking of the Chinese, but also a number of extralinguistic factors that determine the formation and state of activity of the verbalassociative network of representatives of different nations. Such factors are historical experience, cultural and poetic traditions, religious and philosophical ideas, modern cultural and political circumstances of society, and so on. However, the free associative experiment demonstrated the possibility of a similar reaction of all recipients to 
universal stimuli-concepts (for example, "family"), which allows to increase the adequacy of translation.

A promising area of further research is to study the process of translation and the reaction of recipients in the gender aspect.

\section{References}

Bell, R.T. (1991). Translation and Translating: Theory and Practice. New York: Longman Inc.

Bogusławska-Tafelska, M. (2001). Psycholinguistic Mechanisms in Translation. Acta Neophilologica, (III), 11-24.

Clark, J.M., \& Paivio, A. (1991). Dual coding theory and education. Educational Psychology Review, 3(3), 149-210. https://doi.org/10.1007/BF01320076

Dolzhikova, A., Kurilenko, V.B., Biryukova, Yu., \& Glazova, O. (2018). Translationoriented reading of scientific-technical texts vs ordinary reading: psychological and psycholinguistic aspects. XLinguae, 11(2), 24-33. https://doi.org/10.18355/ XL.2018.11.02.03

Dottori, M., Hesse, E., Santilli, M., Vilas, M.G., Martorell, Caro, M., Fraiman, D., Sedeño, L., Ibáñez, A., \& García, A.M. (2020). Task-specific signatures in the expert brain: Differential correlates of translation and reading in professional interpreters. NeuroImage, 209, Article 116519. https://doi.org/10.1016/j. neuroimage.2020.116519

Fenollosa, E. (1968). The Chinese written character as a medium for poetry. In E. Pound (Ed.). San Francisco: City Lights Books.

Holmes, J.S. (1988). The Name and Nature of Translation Studies. In J.S. Holmes (Ed.), Translated!: Papers on Literary Translation and Translation Studies (pp. 66-80). Amsterdam: Rodopi. https://doi.org/10.1163/9789004486669

Isaieva, Natalia. (2021). Ukrainian Poetry in Chinese Translation: Research Data of the Reader's Reception. Available at SSRN: https://ssrn.com/abstract=3952539

Latyshev, L.K. (2000). Tehnologija perevoda [The Technology of Translation]. Moscow: NVI-Tezaurus [in Russian].

Malanyuk, E. (1962). Do rokovyn Lesi Ukrayinky [To the Anniversary of Lesya Ukrainka]. Knyha sposterezhen: Proza - Log-Book: Essays (pp. 91-102). Toronto: Homin Ukrainy [in Ukrainian].

Mbada, C.E, Oguntoyinbo, O.E, Fasuyi, F.O, Idowu, O.A, Odole, A.C, Ayanniyi, O. et al. (2020). Cross-cultural adaptation and psychometric evaluation of the Yoruba version of Oswestry disability index. PLOS ONE, 15(1), Article e0221138. https://doi.org/10.1371/journal.pone.0221138

Nida, E.A., \& Taber, Ch.R. (1982). The Theory and Practice of Translation. Leiden: Published for the United Bible Societies by E.J. Brill.

Nida, E.A. (1964). Toward a Science of Translating, with Special Reference to Principles and Procedures Involved in Bible Translating. Leiden: E.J. Brill. https://doi.org/10.1163/9789004495746

Colman, A.M. (2015). A Dictionary of Psychology (4 $4^{\text {nd }}$ ed.). Oxford: Oxford University Press. 
Ogneva, O.D. (2008). Lesya Ukrayinka i Kytay [Lesya Ukrainka and China]. Skhidni stezhky Lesi Ukrayinky - Lesya Ukrainka's Eastern Paths (pp. 183-206). Lutsk: Volyn Regional Printing House [in Ukrainian].

Ogneva, E.D. (2012). Ge Baotsyuan i Lesya Ukrainka: tvorcheskiy kontakt. K 100-letiyu so dnya rozhdeniya Ge Baotsyuanya [Ge Baoquan and Lesya Ukrainka: Creative Contact. For the 100th Anniversary of the birth of Ge Baoquan]. Kytayeznavchi doslidzhennia - Chinese studies (Vol. 1-2), (Vol. 2, pp. 56-64) [in Russian].

Ogneva, O.D. (1993). Kanon fenliu i osobystyy shlyakh Lesi Ukrayinky [Canon of Fenliu and Lesya Ukrainka's Personal Path]. Skhidnyy svit - The World of the Orient, 2, 94-100 [in Ukrainian].

Osgood, C.E. (1952). The nature and measurement of meaning. Psychological Bulletin, 49(3), 197-237. https://doi.org/10.1037/h0055737

Osgood, C.E., Suci, G.J., \& Tannenbaum, P.H. (1957). The measurement of meaning. Urbana: The University of Illinois Press.

Population Health Methods. (2019). URL: https://www.publichealth.columbia.edu/ research/population-health-methods/content-analysis

Rubets, M.V. (2009). Vliyaniye kitayskogo yazyka na myshleniye i kulturu yego nositeley [Impact of the Chinese language on the thinking and culture of its speakers]. Istoriya Filosofii - History of Philosophy, 14, 111-122 [in Russian].

Schweitzer, A.D. (1988). Teoriya perevoda: Status, problemy, aspekty [The Theory of Translation: Status, Problems, Aspects]. Moscow: Nauka [in Russian].

Serkin, V.P. (2004). Metody psikhosemantiky [Methods of psychosemantics]. Moscow: Aspekt Press [in Russian].

Wang, X., \& Forster, K.I. (2010). Masked translation priming with semantic categorization: testing the sense model. Bilingualism, 13(3), 327-340. https://doi. org/10.1017/S1366728909990502

Zasyekin, S. (2010). Translation as a Psycholinguistic Phenomenon. Journal of Psycholinguistic Research, 39(3), 225-234. https://doi.org/10.1007/s10936-0099134-2

Zheng, B., \& Xiang, X. (2017). The psycholinguistics of Chinese translation. In Ch. Shei \& Zh.-M. Gao (Eds.), The Routledge Handbook of Chinese Translation (pp. 291-306). London; New York, NY: Routledge https://doi. org/10.4324/9781315675725

Lesya Ukrainka. 列霞・乌克兰英卡. (1962). Zhēnguìde yănlèi 珍贵的眼泪 [Precious Tears]. In Mài Shēnhéyì 麦莘禾译 [Mai Shenhe] (Transl). 《世界文学》-World Literature, 7-8, 132-135 [in Chinese].

\section{АНОТАЦІЯ}

Мета дослідження. На основі теорій динамічного перекладу визначити ступінь відповідності психокогнітивної реакції українських та китайських реципієнтів на оригінальний та перекладний тексти поезії-циклу Лесі Українки "Сльози-перли".

Методи. Базовими у цій статmі $\epsilon$ психолінгвістичні методи емпіричного дослідження: метод семантичного дифреренціала Осгуда, контент-аналіз та вільний асоціативний експеримент; використано також інші лінгвістичні 
методи (когнітивний і семантичний аналіз) та загальнонаукові методи (аналіз, синтез, дескрипція та класифрікація мовних фактів).

Результати. На основі попередніх теоретичних досліджень з'ясовано сутнісні характеристики перекладу як психокогнітивного процесу. Стверджується, що ступінь еквівалентності перекладу художнього тексту визначається не лише роботою перекладача, але й емоційно-оцінною реакцією цільових реципієнтів. Важливою є теза, що на сприйняття тексту (оригіналу й перекладу) впливає міжпівкульна асиметрія мисленнєвої діяльності носіїв різних мов (Clark \& Paivio, 1991; Fenollosa, 1968; Zasyekin, 2010). Емпіричне дослідження показало, що "правопівкульне" конкретно-образне мислення китайців лише частково зумовлює ступінь еквівалентності їхнього сприйняття перекладу поезії Лесі Українки. Семантичні профрілі засвідчили досить нейтральну емоційно-оцінну реакцію китайців на стимул-переклад, зумовлену, за нашим переконанням, етнонаціональною специфікою оригінального тексту та різницею в поетичних традиціях. Попри збереження тематичних категорій оригіналу в перекладі, в новому (китайському) семантичному просторі ці категорії почасти набули інших сочіокультурних значень, що сутнісно вплинуло на еквівалентність перекладу.

Висновки. Ступінь відповідності психокогнітивної реакції цільових реципієнтів на оригінал і переклад зумовлюється не лише типом мисленнєвої діяльності носіїв різних мов, але й ряду екстралінгвістичних факторів, котрі зумовлюють формування і стан активності вербально-асоціативної мережі представників різних націй.

Ключові слова: китайська мова, переклад, Леся Українка, динамічна еквівалентність, семантичний диференціал, семантичний простір.

\section{Исаева Наталья, Акимова Алина, Акимова Анастасия \& Чернышова Светлана.} Поэзия Леси Украинки в китайском переводе: психолингвистический аспект

\section{АННОТАЦИЯ}

Цель исследования. На основе теорий динамического перевода определить степень соответствия психокогнитивной реакции украинских и китайских реципиентов на оригинальный и переводной тексты поэзии-цикла Леси Украинки "Слезы-жемчуг".

Методы. Ключевыми в этой статье являются психолингвистические методы эмпирического исследования: метод семантического диффреренциала Чарльза Осгуда, контент-анализ и свободный ассоциативный эксперимент; использованы также другие лингвистические методы (когнитивный и семантический анализ) и общенаучные методы (анализ, синтез, дескрипция и классификация языковых фактов).

Результаты. На основе предыдущих теоретических исследований установлены основные характеристики перевода как психокогнитивного процесса. Утверждается, что степень эквивалентности перевода художественного текста определяется не только работой переводчика, 
но также и эмоционально-оценочной реакцией целевых реципиентов. Важным является тезис о том, что на восприятие текста (оригинала и перевода) влияет межполушарная асимметрия мыслительной деятельности носителей разных языков (Clark \& Paivio, 1991; Fenollosa, 1968; Zasyekin, 2010). Эмпирическое исследование показало, что “правополушарное" образное мышление китайцев частично влияет на степень эквивалентности их восприятия перевода поэзии Леси Украинки. Семантические профили показали достаточно нейтральную эмоционально-оценочную реакцию китайцев на стимулы перевода, обусловленную, по нашему мнению, этнонациональной спецификой оригинального текста и разницей в поэтических традициях. Несмотря на сохранение тематических категорий оригинала в переводе, в новом (китайском) семантическом пространстве эти категории отчасти приобрели другие социокультурные значения, что существенно повлияло на эквивалентность перевода.

Выводы. Степень соответствия психокогнитивной реакции целевых реципиентов на оригинал и перевод определяется не только типом мыслительной деятельности носителей разных языков, но и рядом экстралингвистических факторов, которые влияют на формирование и состояние активности вербально-ассоциативной сети представителей разных наций.

Ключевые слова: китайский язык, перевод, Леся Украинка, динамическая эквивалентность, семантический дифреренциал, семантическое пространство. 